\title{
Investigating The Effect Of Bank Competition On Financial Stability In Ten African Countries
}

Christopher James Hope, Witwatersrand University, South Africa

Tendai Gwatidzo, Witwatersrand University, South Africa

Miracle Ntuli, Witwatersrand University, South Africa

\begin{abstract}
This paper explores the relationship between bank competition and financial sector stability using 2005-2010 data for ten African countries. The study utilises a Generalized Method of Moments approach to regress bank stability indices - Z-score, non-performing loans ratio and return on banks assets - on bank competition indices - Lerner-Index, Herfindahl-Hirschman Index total assets and Herfindahl-Hirschman Index total deposits. The findings show a robust positive relationship between market power and financial stability. This unequivocally suggests that there is a trade-off between bank competition and financial sector stability in these countries, as per the competition-fragility view.
\end{abstract}

Keywords: Market Power; Bank Competition; Africa; Bank Regulation; Market Structure

\section{INTRODUCTION}

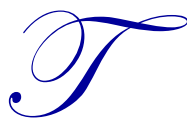

he debate on whether competition among banks is good or bad has always been a contentious one, see for example Vives (2001), Beck (2008), Carletti and Vives (2009), and Beck et al. (2012). The 2007-2009 global financial crisis, however, intensified the debate, with special attention being paid to bank regulation. According to Beck (2008), the right balance between competition and regulation is required. Competition mixed with the wrong kind of regulation can be a dangerous concoction. This debate is especially important given the mergers and acquisitions, as well as the financial-sector liberalisation witnessed in a number of developing countries, including African countries (Vives, 2001).

There are a number of reasons why competition among banks may be welfare enhancing. Competition forces banks to be more efficient and innovative regarding the development of new products and providing better banking services. The quest for profits in a highly competitive environment can force banks to devise techniques that facilitate efficient borrower screening and monitoring. Competition also tends to put downward pressure on lending rates while increasing deposit rates, benefiting both borrowers/entrepreneurs and depositors (Beck, 2011). The lower interest rates faced by borrowers also reduce information asymmetry problems like moral hazard, ultimately reducing bank fragility.

Competition can also force banks to look for other clients outside the normal working class (Keeley, 1990; Beck, 2011). These may include the previously unbanked groups in society, thereby increasing access to finance $\left(\right.$ Beck, 2011) ${ }^{1}$. For example, mobile banking has resulted in an increase in finance in a number of African countries. For instance, in Kenya a payment service called M-Pesa was introduced. The facility allows the cellular handset to perform a number of financial services, including making payments and doing internet banking (Nkurunziza, et al., 2012). In South Africa, a number of banks introduced the Mzansi account, which is primarily targeted at lowincome groups. Ultimately, all this tends to broaden the customer base of the financial system resulting in better risk

\footnotetext{
${ }^{1}$ Especially in Africa where the proportion of people without banking services is still very high (Beck, et al., 2001)
} 
diversification (Beck, 2011). This is supported by Berger et al. (2004) who found that lack of competition in the banking sector can also contribute to reduced access to finance for smaller firms and a country's very poor.

However, excessive competition in the banking sector can be harmful to the economy as it can undermine bank franchise value, incentivising banks to take excessive risks. This may lead to herding trends, with financial institutions taking similar risks and ultimately increasing systemic fragility and contagion risk (Beck, 2011). Also, banking systems characterised by a few large banks may be good for the economy as large banks can easily diversify across sectors and regions, reducing instability.

Given the advantages and disadvantages of competition in the financial sector, it is not surprising that there is no general consensus on whether competition among banks leads to financial-sector stability (Vives, 2001). Following Berger et al. (2009) and using a sample of banks from ten African countries and covering the period 2005-2010, this study aims to investigate the relationship between bank competition and financial stability. It seeks to investigate whether competition fosters or undermines financial-sector stability.

From a policy perspective, the banking sector plays a pivotal role in any given economy. An understanding of the relationship between bank competition and financial-sector stability is therefore important for policy as it helps ensure the right mix between competition and regulation. Recent literature has been driven by the motivation of policy concerns as to what type of market structure leads to the most efficient and stable operating environment for banking firms (Lui et al., 2010). After the financial collapse in 2008, there has been renewed interest in the relationship between competition, stability and regulation. Hoggarth and Saporta (2001) showed that the fiscal cost of a financial crisis can be as high as 17\% of GDP for a developing economy. The banking sector forms the financial backbone of every economy, hence an understanding of the core dynamics that affect stability is of vital importance. Also, there is no consensus in the extant literature on the optimal level of financial-sector regulation (Vives, 2001). Berger et al. (2004) argue that despite recent studies on banking in developing countries, further research on banking stability in developing nations is still needed.

African countries are interesting to study for a number of reasons. Firstly, they are less developed and their financial systems are still at an embryonic stage of development. They can therefore learn a lot from developed economies, including from mistakes made by developed economies. For example, one lesson learnt from the current global financial crisis is that African countries must be careful not to import everything that appears to work in developed economies. Another lesson is that as they develop, African countries must come up with systems that do not create perverse incentives among the different players in the financial sector. For example, the role of players, like the credit-rating agencies, investment banks, and the regulators, must be well defined.

\section{LITERATURE REVIEW}

At the centre of the debate on the relationship between bank competition and stability are two main hypotheses - the competition-stability view (also known as concentration-fragility view, charter or franchise-value view) and the competition-fragility view (also known as concentration-stability view).

The competition-fragility view, as modelled by Keeley (1990) and Marcus (1984), postulates that competition undermines stability and market power is stability enhancing. That is, there is a trade-off between competition and stability. According to this view, competition, by lowering profits, lowers a bank's franchise value, which increases moral hazard as banks take on excessive risk to accommodate the lower margins received in the competitive loan market (Hellman et al., 2000) $)^{2}$. On the contrary, in less competitive environments, banks earn monopoly rents resulting in higher bank profits and higher franchise values. The high franchise values discourage banks from taking excessive risks as they try to protect their increased franchise values (Lui et al., 2010). Less competitive environments also imply that the incumbent banks have higher probabilities of getting more lucrative business opportunities and higher capital cushions ${ }^{3}$ - something that may enable them to withstand shocks. This

\footnotetext{
${ }^{2}$ In Boot, Greenbaum and Thakor (1993) it is, however, argued that bank reputation and the private cost of failure of managers reduces the incentive for banks to take on more risk when competition increases.

${ }^{3}$ With some of the profits being retained and not issued as dividends, hence increasing the firm's capital base. 
implies that they do not have excessive pressure to take excessive risk. This view is also supported by Boot et al. (1993) who argue that greater market power allows banks to protect their franchise value by generating larger capital buffers, which make bank managers act more prudently and pursue lower-risk strategies.

There are a number of studies that find supporting evidence for the competition-fragility view. These include Keeley (1990), Allen and Gale (2000; 2004), Besanko and Thakor (2004), Edwards and Mishkin (1995). Using data on US banks, Keeley (1990) investigated the effect of market structure on bank risk and found that banks try to protect the franchise value emanating from their market power by keeping their lending risk relatively low. Saunders and Wilson (1996) also used US banks for a longer sample period and found evidence corroborating Keeley (1990)'s findings. Hellman et al. (2000) argue that the increased competition in the Japanese financial sector, chiefly caused by the country's financial liberalisation in the 1990s, reduced financial stability and may have contributed to the East Asian financial crisis (Jimenez et al., 2010). Allen and Gale (2000; 2004) found results suggesting that a concentrated banking system is likely to be more stable due to banks being more profitable, more diverse and easier to monitor. Besanko and Thakor's (2004) study supported the view that increased competition induces banks to choose riskier portfolio strategies. Edwards and Mishkin (1995) also argued that competition tends to reduce a bank's cost advantage in the acquisition of funds and undermines its position in the loan market. In their comprehensive literature review on the competition-stability nexus, Carlett and Vives (2008) conclude that market power has a moderating effect on the risk-taking behaviour of banks. Using a sample of 821 banks from 60 developing countries, Turk-Ariss (2010) found a positive relationship between market power and financial stability, suggesting that increased market power may improve bank soundness and possibly economic stability (Turk-Ariss, 2010).

The competition-stability view posits that there is no trade-off between competition and stability. In fact, competition fosters stability and higher market power is associated with financial instability. This view, as theoretically developed in Boyd and Runkle (1993) and Mishkin (1999), is predicated on two main arguments - the too-big-to-fail problem and the too-big-to-monitor problem. The former argument emanates from the fact that banks operating in highly concentrated markets can become so large, so pivotal for the economy, and so interconnected that their failure tends to impose huge social costs on the society and can be catastrophic for the entire economy, and therefore must be supported by the government when facing bankruptcy. This high probability of bailout for the large banks may create problems of moral hazard as there is a high incentive for banks to take excessive risks knowing that in the event of failure, the government will bail them out. This may result in financial-sector fragility. The latter argument states that the size of a bank is positively related to its complexity, thus small banks are easier to monitor and regulate than large banks. Hence, large banks are also associated with the so-called too-complex-tomonitor problem. This may encourage them to take excessive risks, knowing that regulators may not notice the excessive risks to which the banks may be exposed. Boyd and De Nicolò (2005) take a different tack trying to demonstrate the positive relationship between competition and stability. They argue and demonstrate that lower lending rates that are associated with a more competitive banking sector are good for entrepreneurs (or borrowers) as they lower the cost of borrowing and increase the probability of success of the entrepreneurs' projects. The success of borrowers' projects also reduces their probability of default, which reduces credit risks and ultimately bank fragility (Beck et al., 2012).

The concentration-fragility view is largely driven by the neoclassical paradigm, which states that an increase in firm competition in a given economic sector will lower monopoly rents and create a more efficient sector. The view that competition should be good in the banking sector, just as it is good in the other economic sectors, may not necessarily be true. As argued above, by lowering franchise value, competition among banks may actually worsen moral hazard problems as banks are forced to take on excessive risk to accommodate the lower margins received in the loan market (Hellman et al., 2000). However market power, by moderating and dampening risk-taking incentives of bank managers, can actually be associated with financial stability (Vives, 2001; Keeley, 1990; and Hellman, Murdock and Stiglitz, 2000).

Studies that find supporting evidence for the concentration-fragility view include Boyd et al. (2006), De Nicolo and Loukoianova (2007, and Uhde and Heimeshoff (2009). Using separate banking data sets; one on US banks and the other on banks from more than 100 countries, Boyd et al. (2006) investigated the relationship between financial stability and market structure and found a negative relationship between the Z-score (a measure of 
financial stability) and the HHI (a measure of market power), suggesting that an increase in market power tended to reduce financial sector stability. This is further supported by Uhde and Heimishoff (2009) who used data on a sample of 2600 EU banks covering the period 1997-2005. Similar results were also found by De Nicolo et al. (2004). De Nicolo et al. (2004) used a sample of 500 of the largest financial institutions, covering the period 19932000 , to investigate the impact of bank consolidation on financial stability and found that more concentrated banking systems tended to have higher levels of systemic risk than less concentrated systems. De Nicolo and Loakoianova (2007), using bank data from 133 non-industrialised countries covering the period 1993-2004, investigated the relationship between bank failure and market structure inter alia. They found a positive relationship between concentration and bank failure, with the robustness of the result improving with an increased involvement of government-owned banks (which were found to have higher risk profiles than private-owned banks). The competition and stability test for this study closely follows Berger, Klapper and Turk-Ariss (2009) and aims to regress competition measures on stability measures.

\section{METHODOLOGY AND DATA}

The paper uses data on banks from ten African countries. It covers the period 2005-2010 and includes South Africa, Nigeria, Algeria, Ivory Coast, Egypt, Tunisia, Morocco, Sudan, Ghana and Kenya. The focus of the methodology is to evaluate the extent to which competition affects bank stability. Following Berger et al. (2009), the study uses a series of market structure and stability variables to estimate the relationship between competition and stability. The relationship that we seek to test can be mathematically represented as follows:

Financial Stability $=f($ Market structure, Banks controls, Business Environment)

The study follows three steps to determine the relationship between market structure and stability. The first step involves measuring stability. The second step is to quantify competition. The last step is to run regressions of financial stability on market power measures and a number of control variables. This is done using the Generalised Methods of Moments (GMM) approach. The study follows the intermediation approach, which assumes that a bank uses inputs, such as labour and capital to receive deposits, to then create loans and increase total assets.

Financial Stability Indicators - Following Berger et al. (2009), we use the Z-index, the Non-Performing Loans to gross loans (NPL) ratio and Return on Assets (ROA) to measure financial stability. The Z-index is an inverse proxy variable for the probability of the firm failing and is thus used as a direct measure of stability. It was first developed by Roy (1952) and then later used in empirical banking studies by Boyd et al. (2009), Berger et al. (2009) and TurkAriss (2010), among others. Higher bank capitalisation, and thus stability, is represented by a higher Z-index, with unstable earnings represented by a lower Z-index. Thus, an increase in the Z-index indicates more stability and a decrease in the Z-index indicates instability. One index variable is calculated per firm over the sample period. The Z-index represents the number of standard deviations below the mean by which the profits of the bank would have to fall so as to completely deplete equity capital (Boyd et al., 2009). It is a measure of a bank's distance to insolvency and is formally defined as:

$$
Z_{i}=\frac{\overline{R O A}_{i}+\overline{E A}_{i}}{\bar{\sigma}_{R O A_{i}}}
$$

where $Z_{i}$ is the inverse probability of failing (the Z-index), $R O A_{i}$ is the period-average returns on assets for bank $i$, $E A_{i}$ is the period-average equity to total assets for bank $i$, and $\sigma_{R O A i}$ is the period-average standard deviation on the returns to assets for bank $i$. The NPL proxy variable is a bank-level ratio of the non-performing loans to total loans. The non-performing ratio is averaged over the period of the study, thus resulting in one data point per bank over the sample period. 
Competition Index - Following Berger et al. (2009), we used the Lerner Index to quantify market structure. The Lerner index represents the mark-up of price over marginal costs and is an indicator of market power ${ }^{4}$. The fundamental policy concern over market power is the association of prices above marginal cost with the reduction in output quantity below the perfect competition level. The test to measure the mark-up of the banking products is based on the established principle that profit-maximising firms in equilibrium will choose prices or quantities such that marginal cost equals their marginal revenue. This price coincides with the demand price under perfect competition, but with the industry's marginal revenue under perfect collusion (Shaffer, 2004). The index is calculated on bank-level data and uses the quantity in which the product price exceeds the marginal cost (Berger, Klapper and Turk-Ariss, 2009). The index calculated is averaged over the period of the study for each bank. The index can be formally expressed as follows:

$$
L I_{i t}=\frac{\left(P_{i t}-M C_{i t}\right)}{P_{i t}}
$$

where $L I_{i t}$ is the Leaner Index for bank $i$ at time $t, P_{i t}$ is the ratio of total revenues (interest and non-interest income) to total assets for bank $i$ at time $t$ (Proxy for the price of total assets), and $M C_{i t}$ is the marginal cost of the total assets for bank $i$ at time $t$. We follow Berger et al. (2009) and Beck et al. (2012) in estimating the marginal cost for each firm. The estimation of the Lerner Index requires a quantification of the marginal cost of the total assets for each bank. Most empirical studies on banking have used a functional form of marginal cost derived from the translogarithmic (translog) total-cost function (see, for example, Shaffer, 1993; Carbó et al., 2009; Berger et al., 2009). The translog cost function has the advantage of being directly compatible with the theoretically required homogeneity conditions, without the use of additional parameters (Shaffer, 2003). Translog equations are derived using three input costs; namely, personnel expenses, capital expenses and deposit expenses (Berger et al, 2009). We estimate the marginal cost by firstly estimating the translog cost function and then deriving the marginal cost from the cost function. We assume a bank is producing a single aggregate output $\left(Q_{i t}\right)$ using three inputs (labour, funds and fixed capital), the prices of which are given by $W_{l i t}, W_{2 i t}, W_{3 i t}$, respectively. The input price of labour is calculated as total staff expenses divided by total assets. The input price for the funds is the ratio of interest expense to total deposits ratio and that of fixed capital is other operating costs divided by total assets. The following specification was used to estimate the cost function:

$$
\ln C_{i t}=a_{0}+a_{1} \ln Q_{i t}+a_{2}\left(\ln Q_{i t}\right)^{2}+\sum_{j=1}^{3} \beta_{j} \ln w_{j i t}+\sum_{j=1}^{3} \sum_{k=1}^{3} \beta_{j k} \ln w_{j i t} \ln w_{k i t}+\sum_{j=1}^{3} \gamma_{j} \ln w_{j i t} \ln Q_{i t}+\varepsilon_{i t}
$$

In line with Berger et al. (2009) and Beck et al. (2012), the above equation was estimated separately for each country. Marginal costs $\left(M C_{i t}\right)$ for each firm $i$ was then calculated as follows:

$$
M C_{i t}=\frac{C_{i t}}{Q_{i t}}\left[a_{1}+2 a_{2} \ln Q_{i t}+\sum_{j=1}^{2} \gamma_{j} \ln \frac{w_{j i t}}{w_{i t}^{3}}\right]
$$

\subsection{Competition and Stability Regression}

A major restriction when using the Lerner Index is that it does not account for possible endogeneity that may arise between market structure and stability. The Efficient Structure Hypothesis postulates that efficiency and stability may be driving market structure (Turk-Ariss, 2010). In order to account for the possible endogeneity, the model implements the Generalised Method of Moments (GMM) estimation using instrumental variables introduced by Hansen (1982). The GMM estimator is more efficient than the two-stage least square estimator because it allows for heteroskedasticity (Hall, 2005). In order to control for bank-specific heterogeneity, we include two variables that

\footnotetext{
${ }^{4}$ It should be noted that the manner in which the Lerner Index is constructed, does not capture any form of risk premia in the price of banks' products and services. Thus this does break down the positive association between risk premia and the size of monopoly rents (Berger, Klapper and Turk-Ariss 2009).
} 
measure bank size and asset composition. Bank size is measured using the log of total assets and asset composition is measured using share of total loans to total assets. To control for country-specific heterogeneity, an index of legal business rights, as well as business regulation, are included as control variables. The log value of GDP per capita and the percentage of foreign ownership are the final control variables used to control for variations in economic development. Thus, the final model that we tested can be formally expressed as follows:

$$
S_{i k}=\beta_{0}+\beta_{1} M P_{i k}+\beta_{3} L T A_{i k}+\beta_{4} F A T_{i k}+\beta_{5} \ln (T A)_{i k}+\beta_{6} L R_{k}+\beta_{7} \ln (G D P)_{k}+\beta_{8} F O_{k}+\varepsilon_{t}
$$

where $S_{i k}$ is the stability index (either the Z-index, ROA, non-performing loans) for firm $i$ in country $k, L T A_{i k}$ is the ratio of loans to total assets for firm i in country $\mathrm{k}$ (proxy variable for bank-asset composition), $F A T_{i k}$ is the bank heterogeneity control variable - the ratio of fixed assets to total assets for firm $i$ in country $k, \ln (T A)_{i k}$ is the $\log$ of total assets of bank $i$ in country $k$ (proxy variable for bank size), $L R_{k}$ is the legal business-rights index for country $k$, $\ln (G D P)_{k}$ is the country heterogeneity control variable - the log of real Gross Domestic Product per capita, and $\mathrm{FO}_{\mathrm{k}}$ is the percentage of foreign ownership of banks in country $k$.

\subsection{Data}

The data for the study were collected from several sources. The information on bank financial and income statements was obtained from BankScope. Bankscope is a comprehensive database collected by Fitch containing information on banks from across the globe. Information on macroeconomic indicators, like GDP, was obtained from the World Development Indicators online database. Table 1 shows the variables used in the study, the definition of the variables, and their sources. The study involves the collection of three competition indices, as well as three stability indices, while including bank-level control variables and country-level control variables to account for systematic variation over ten African countries for the period of 2005-2010. The empirical methodology that was implemented in this study follows closely that used by Berger et al. (2009).

Table 1: Variable Definition and Data Sources

\begin{tabular}{|c|c|}
\hline Variable & Definition \\
\hline \multicolumn{2}{|l|}{ Dependent Variables } \\
\hline Z-Index & $\begin{array}{l}\text { Bank level stability indicator. Inverse measure of financial health of a bank, the higher } \\
\text { the Z-Index, the better the bank's financial health. Source: Fitch IBCA's Bankscope } \\
\text { Database, known as Bankscope in short. }\end{array}$ \\
\hline NPL & $\begin{array}{l}\text { Ratio of non-performing loans to the gross number of loans. The greater the ratio a } \\
\text { bank has, the riskier the loan portfolio of the bank. Source: Bankscope }\end{array}$ \\
\hline ROA & $\begin{array}{l}\text { Return on assets, this dependent variable measures banks profitability. Source: } \\
\text { Bankscope }\end{array}$ \\
\hline \multicolumn{2}{|r|}{ Sunsol } \\
\hline Lerner Index & $\begin{array}{l}\text { A competition indicator that uses pricing above the product cost to determine the } \\
\text { competitive environment in which the bank operates. Higher Lerner Indices indicate } \\
\text { more market power and less competition. Source: Bankscope }\end{array}$ \\
\hline HHI Assets & $\begin{array}{l}\text { A competition proxy variable that calculates the square of the bank assets to total } \\
\text { market assets to determine the market power of each bank in the banking sector. } \\
\text { Source: Bankscope }\end{array}$ \\
\hline HHI Deposits & $\begin{array}{l}\text { A competition proxy variable that calculates the square of the bank deposits to total } \\
\text { market deposits to determine the market power of each bank in the banking sector. } \\
\text { Source: Bankscope }\end{array}$ \\
\hline \multicolumn{2}{|l|}{ Control Variables } \\
\hline LTA & Ratio of gross loans to total assets, calculated at the firm level. Source: Bankscope \\
\hline FAT & Ratio of fixed assets to total assets, calculated at the firm level. Source: Bankscope \\
\hline $\operatorname{lnTA}$ & The natural logarithm of total assets, calculated at the firm level. Source: Bankscope \\
\hline $\operatorname{lnGDP}$ & $\begin{array}{l}\text { The natural logarithm of the country's GDP per capita. Calculated at a country level. } \\
\text { Source: Bankscope }\end{array}$ \\
\hline
\end{tabular}




\begin{tabular}{|l|l|}
\hline $\mathrm{FO}_{\mathrm{k}}$ & Percentage of foreign-owned banks. Source: Barth, Caprio and Levine (2001) ${ }^{5}$. \\
\hline $\mathrm{LR}$ & $\begin{array}{l}\text { The legal-rights index ranges between } 0 \text { and 10, where } 10 \text { indicate strong legal rights } \\
\text { and 0 indicate weak legal rights. Source: World Bank }\end{array}$ \\
\hline Instrumental Variables & \multicolumn{1}{|c|}{$\begin{array}{l}\text { Activity restrictions index ranges from } 4 \text { to } 16 \text { with } 4 \text { indicating the banks have little- } \\
\text { to-no restrictions and 16 indicating the banking sector is heavily restricted. Source: } \\
\text { Barth, Caprio and Levine (2001). }\end{array}$} \\
\hline Activity Restrictions & $\begin{array}{l}\text { The index measures the extent to which financial service providers can freely operate } \\
\text { without government intervention. The extent of government intervention in the sector } \\
\text { could be in the form of: restricting foreign bank ownership, government influence on } \\
\text { credit allocation, etc. The higher the index, the more restricted is the banking sector. } \\
\text { Source: Heritage Foundation online database. }\end{array}$ \\
\hline Banking Freedom & $\begin{array}{l}\text { Government ownership is a percentage expressed as a value between } 0 \text { and } 100 . \\
\text { Source: Barth, Caprio and Levine (2001). }\end{array}$ \\
\hline
\end{tabular}

The study was restricted to testing all commercial banks within the sample countries. Table 2 shows the countries and the number of banks used in the study.

Table 2: Sample Countries And The Number Of Banks Included In The Study

\begin{tabular}{|l|c|}
\hline \multicolumn{1}{|c|}{ Country } & Number of Commercial Banks \\
\hline South Africa & 16 \\
\hline Egypt & 23 \\
\hline Nigeria & 19 \\
\hline Algeria & 14 \\
\hline Morocco & 10 \\
\hline Sudan & 14 \\
\hline Tunisia & 14 \\
\hline Ghana & 21 \\
\hline Kenya & 31 \\
\hline Ivory Coast & 8 \\
\hline Total & $\mathbf{1 7 0}$ \\
\hline
\end{tabular}

Source: BankScope

Stability Indices - The study uses three proxies to quantify banking-sector stability: the Z-index, the NPL ratio and ROA. The indices are obtained from each of the bank's financial statements, which are obtained from the BankScope database. The Z-index and the NPL are averaged over the six-year sample period, resulting in one data point per firm over the 2005-2010 period.

Competition Indices - The Lerner Index was calculated using the total cost, total revenue, and total-assets data. All data required for the construction of the Lerner Index were obtained from the financial statements of each bank and from BankScope. The Lerner Index was constructed for each firm per year and then averaged over the period of the study to get one index per firm over the sample period. Two additional competition indices are used in the study: the Herfindahl-Hirschman Index using deposits (HHI deposits) and the Herfindahl-Hirschman Index using total assets (HHI assets). The HHI deposits are calculated by summing the total number of deposits in the country and then squaring the ratio of bank deposits to industry-wide deposits. The same is done for the assets of the bank in order to collect the HHI assets data. The data for the competition indices are summarised in Table 3. Most of the variables used are ratios; therefore, they do not need to be converted to US dollars before use. However, where necessary, the data were converted to US dollars. It must be noted that the Bankscope database already converts the data to US dollars using appropriate exchange rates. The macroeconomic data were also converted to US dollars using appropriate exchange rates.

\footnotetext{
${ }^{5}$ As updated in 2012.

${ }^{6}$ World Banks's "Doing Business" database
} 
Table 3: Data Sources And Summary Statistics

\begin{tabular}{|l|c|c|c|c|c|c|}
\hline \multicolumn{1}{|c|}{ Variable } & Obs. & Mean & Std. Dev. & Min & Max & Data Source \\
\hline Z & 170 & 44.10 & 96.97 & -0.60 & 833.13 & Bankscope \\
\hline NPL & 170 & 8.96 & 20.84 & 0.00 & 244.28 & Bankscope \\
\hline ROA & 170 & 1.24 & 2.43 & -12.98 & 9.35 & Bankscope \\
\hline Lerner & 170 & 0.40 & 0.66 & -2.03 & 8.03 & Bankscope \\
\hline HHITD & 170 & 98.23 & 289.12 & 0.00 & 2637.16 & Bankscope \\
\hline HHITA & 170 & 101.68 & 318.49 & 0.00 & 3217.32 & Bankscope \\
\hline GDPpc & 170 & 1333.07 & 1090.10 & 324.06 & 3647.45 & World Bank Development Indicators \\
\hline AR & 170 & 3.10 & 1.45 & 1.00 & 6.00 & Barth, Caprio and Levine \\
\hline GO & 170 & 17.80 & 15.57 & 0.00 & 42.70 & Barth, Caprio and Levine \\
\hline BF & 170 & 9.70 & 1.42 & 8.00 & Heritage Foundation \\
\hline
\end{tabular}

Notes: Z stands for the Z-index, NPL stands for non-performing loans, ROA stands for Returns on Assets, Lerner stands for the Lerner Index, HHITD stands for Herfindahl-Hirschman Index using deposits, HHITA stands for Herfindahl-Hirschman Index using total assets, AR stand for Activity Restrictions Index, GO stands for percentage of Government-Owned Bank, BF stands for Banking-Freedom Index

\subsection{Estimation of the Competition-Stability Relationship}

The purpose of the study is to estimate the relationship between the competition index and the stability index. In order to account for variances across countries, the study incorporates control variables suggested by Berger et al. (2009). The control variables include the loans to total assets, the fixed assets to total assets, and the natural logarithm of total assets. These variables are bank-specific control variables and one data point is taken per bank over the six years. The next set of control variables accounts for country-specific effects, such as the legal business-rights index, which is collected from the World Bank's "Doing Business" database. The legal-rights index ranges between 0 and 10, where 10 indicates strong legal rights and 0 indicates weak legal rights. The percentage of foreign ownership controls any external influence that occurs in a country's banking sector. The last control variable, GDP per capita, is collected from the World Bank's World Developing Indicators database.

Instrumental Variables - To account for endogeneity of market power and heterogeneity across countries, the Generalised Method of Moments using instrumental variables is implemented. The econometric methodology used here is taken from Berger et al. (2009) and uses activity restrictions, banking freedom, and percent of governmentowned banks as instrumental variables. The data for the instrumental variables was collected from Heritage Foundation and Barth et al (2001). The data from Barth et al. (2001) was updated in 2012.

\section{RESULTS}

The results of the study are presented in Tables 4-6. We use three indicators as proxies for financial stability. These are the Z-index (used as the dependent variable in Table 4), the NPL (used as the dependent variable in Table 5) and ROA (used as the dependent variable in Table 6). There are three models in each table. Model 1 runs the financial-stability indicator on the Learner Index (measure of market power) and other common control variables. Model 2 runs the financial-stability indicator on HHID (HHI Deposits) and other control variables. Finally, Model 3 runs the financial-stability indicator on HHITA (HHI Total Assets) and other control variables. An increase in each indicator of market power (that is the Lerner Index, HHITA and HHID) implies an increase in market power or a decrease in competition. The First-Stage F-test was used to test for the relevance of the instrumental variables used. The Hansen's J-test was used to test for the validity of the instrumental variables. The results from the Hansen's J-test show that the instrumental variables are valid in all regressions and the results from the First-Stage F-tests confirm that the instruments are relevant. In terms of methodology, we closely follow Berger et al. (2009) and utilise a GMM estimator with robust standard errors. The instruments used were banking-activity restrictions, banking freedom and the percent of government-owned banks. The regressions also include an indicator for legal rights, the log of GDP per capita and the percentage of foreign ownership to account for cross-country heterogeneity. The ratio of total loans to total assets, fixed assets to total assets, and the natural log of bank-total assets are used to further control for bank-specific heterogeneity. 
Table 4: The Effect Of Market Power On The Z-Index

\begin{tabular}{|l|c|c|c|}
\hline Explanatory Variables & $\begin{array}{c}\text { Model 1 } \\
\text { (Lerner Index) }\end{array}$ & $\begin{array}{c}\text { Model 2 } \\
\text { (HHI Deposits) }\end{array}$ & $\begin{array}{c}\text { Model 3 } \\
\text { (HHI Total Assets) }\end{array}$ \\
\hline Degree of Market Power & $75.471^{*}$ & -0.048 & $\left(.750^{* * *}\right.$ \\
\hline & $(38.45)$ & $(0.65)$ & $(0.165)$ \\
\hline Loans to Total Assets & $0.741^{* *}$ & 0.341 & $(3.161$ \\
\hline & $(0.35)$ & 2.621 & -45.236 \\
\hline lnTA (Bank Size) & -1.273 & $(3.89)$ & $(138.72)$ \\
\hline & $(3.80)$ & 0.529 & $0.736^{* * *}$ \\
\hline Fixed Assets to Total Assets & 3.511 & $(2.34)$ & $(0.150)$ \\
\hline & $(4.21)$ & $8.352^{* * *}$ & $-98.412^{* * *}$ \\
\hline lnGDP & $10.340 * * *$ & $(2.39)$ & $(25.35)$ \\
\hline & $(2.07)$ & 0.231 & -4.031 \\
\hline Foreign Ownership & $0.625 * *$ & $(0.203)$ & $(10.64)$ \\
\hline & $(0.232)$ & -0.341 & -14.221 \\
\hline Legal Rights & 4.231 & $(2.81)$ & $(35.27)$ \\
\hline & $(3.96)$ & -21.362 & $(54.23)$ \\
\hline Constant & $-130.281 *$ & 168 & $(374.33)$ \\
\hline
\end{tabular}

Notes: ***, **, * stand for significance levels at the 1\%,5\% and 10\%. Models 1, 2 and 3 regress the Z-index on Lerner Index, HHI Deposits and HHI Total Assets (measures of market power) respectively. Included in each model are common control variables.

Table 4 shows the results when using the Z-index as the proxy for financial stability. The Z-index is derived from adding ROA and the ratio of equity to total assets and then dividing the result by the standard deviation on the returns to a bank's assets. An increase in the Z-index implies an increase in financial stability. An increase in profitability and a reduction in leverage increases the Z-index while an increase in the standard deviation on returns to assets reduces the index and indicates an increase in bank instability. Results from Models 1 and 3 in Table 4 show that there is a positive and significant relationship between market power and financial stability, supporting the concentration-stability view. Our results using data on African firms also corroborate findings by Allen and Gale (2000; 2004), Besanko and Thakor (2004), and Edwards and Mishkin (1995). The results in Table 4 also show the importance of other control variables. For example, we find a positive relationship between real GDP per capita and financial stability. This result is consistent and robust across the different definitions of market power. Model 1 also shows a positive relationship between foreign ownership and financial stability. Financial stability is also positively related to the total loans-total-assets ratio. In Model 3, we also find a positive relationship between the fixed-assets ratio to total-assets ratio and financial stability.

Table 5 shows results for regressions of NPL ratio on degree of market power and other covariates. The NPL ratio is calculated as NPL divided by total loans. An increase in the ratio indicates a decrease in financial stability and vice versa. Model 1 uses the Lerner Index as a proxy for market power, Model 2 uses HHID, and Model 3 uses the HHITA. Results for all models show a negative and statistically significant relationship between the NPL ratio and the three measures of market power, suggesting that an increase in market power is stabilityenhancing. This implies that imperfect markets may be good for stability. This finding, which confirms the competition-fragility view, harmonises with Keeley (1990), Allen and Gale (2000; 2004), Besanko and Thakor (2004), and Edwards and Mishkin (1995).

As for the other covariates, we find a consistent and significant negative relationship between NPL ratio and GDP per capita in Models 1 and 3. Mixed results are found for the relationship between NPL ratio and bank size. A positive relationship is found in Models 2 and 3 and a negative relationship is obtained in Model 1. The positive outcome could be due to bigger banks investing in large-scale operations, which could cause increased risk through lack of sufficient diversification. The negative relationship between bank size and NPL ratio could be the 
result of more successful portfolio selection in larger banks than in smaller ones. This could be explained by larger banks having larger budgets to employ more skilled workers, or other more sophisticated screening techniques (Berger et al., 2009). The GDP per capita coefficients of -2.45 and -3.49 (in Models 1 and 3) confirm our expectation that a country with a high GDP per capita tends to have a more mature banking sector, which will have a more evolved portfolio-selection process. Thus high-income countries tend to have more stable banking systems. The loans-to-total-assets ratio is positively related to the NPL ratio in Model 1, implying that banks that loan out more money relative to their assets tend to have riskier loan portfolios. Mixed results are also found on the relationship between foreign bank ownership and financial stability.

Table 5: The Effect Of Market Power On NPL

\begin{tabular}{|c|c|c|c|}
\hline Dependent Variable: NPL & $\begin{array}{c}\text { Model 1 } \\
\text { (Lerner Index) }\end{array}$ & $\begin{array}{c}\text { Model } 2 \\
\text { (HHI Deposits) }\end{array}$ & $\begin{array}{c}\text { Model 3 } \\
\text { (HHI Total Assets) }\end{array}$ \\
\hline \multirow{2}{*}{ Degree of Market Power } & $-18.514^{*}$ & $-0.065^{* * *}$ & $-0.068 * * *$ \\
\hline & $(9.54)$ & $(0.017)$ & $(0.016)$ \\
\hline \multirow[t]{2}{*}{ Loans to Total Assets } & $0.139 * * *$ & 0.024 & 0.021 \\
\hline & $(0.04)$ & $(0.084)$ & $(0.88)$ \\
\hline \multirow[t]{2}{*}{$\operatorname{lnTA}$ (Bank Size) } & $-1.160 *$ & $2.851 * * *$ & $3.914 * * *$ \\
\hline & $(0.59)$ & $(0.79)$ & $(0.856)$ \\
\hline \multirow[t]{2}{*}{ Fixed Assets to Total Assets } & 0.355 & 0.142 & 0.131 \\
\hline & $(0.55)$ & $(0.57)$ & $(0.42)$ \\
\hline \multirow[t]{2}{*}{$\operatorname{lnGDP}$} & $-2.450 *$ & -1.821 & $-3.492 *$ \\
\hline & $(1.25)$ & $(1.35)$ & $(1.99)$ \\
\hline \multirow[t]{2}{*}{ Foreign Ownership } & -0.085 & $0.354 * * *$ & $-6.580 * * *$ \\
\hline & $(0.25)$ & $(0.02)$ & $(1.14)$ \\
\hline \multirow[t]{2}{*}{ Legal Rights } & -0.485 & -0.685 & -0.799 \\
\hline & $(0.45)$ & $(0.74)$ & $(0.75)$ \\
\hline \multirow[t]{2}{*}{ Constant } & $24.45^{*}$ & $15.498 * * *$ & $17.576^{* * * *}$ \\
\hline & $(12.32)$ & $(3.10)$ & $(2.69)$ \\
\hline Number of Banks & 168 & 168 & 168 \\
\hline First stage F-Test & 5.96 & 10.33 & $10.7 ; 9$ \\
\hline Prob $>F$ & 0.000 & 0.000 & 0.000 \\
\hline Hansen's J & 0.850 & 0.021 & 0.035 \\
\hline P-value & 0.532 & 0.120 & 0.850 \\
\hline
\end{tabular}

Notes: $* * *, * * *$ stand for significance levels at the $1 \%, 5 \%$ and $10 \%$. Models 1,2 and 3 regress NPL on Lerner Index, HHI Deposits and HHI Total Assets (measures of market power) respectively. Included in each model are common control variables.

Table 6: The Effect Of Market Power On ROA

\begin{tabular}{|c|c|c|c|}
\hline Dependent Variable: ROA & $\begin{array}{c}\text { Model 1 } \\
\text { Lerner Index } \\
\end{array}$ & $\begin{array}{c}\text { Model } 2 \\
\text { HHI Deposits } \\
\end{array}$ & $\begin{array}{c}\text { Model 3 } \\
\text { HHI Total Assets } \\
\end{array}$ \\
\hline \multirow[t]{2}{*}{ Degree of Market Power } & $0.538 * * *$ & $0.783 * * *$ & $0.580 *$ \\
\hline & $(0.152)$ & $(0.198)$ & $(0.31)$ \\
\hline \multirow[t]{2}{*}{ Loans to Total Assets } & -0.015 & 0.005 & -0.021 \\
\hline & $(0.01)$ & $(0.54)$ & $(0.78)$ \\
\hline \multirow[t]{2}{*}{ InTA (Bank Size) } & -0.097 & -0.591 & -0.311 \\
\hline & $(0.11)$ & $(0.93)$ & $(0.27)$ \\
\hline \multirow[t]{2}{*}{ Fixed Assets to Total Assets } & -0.189 & -0.202 & $-0.350 *$ \\
\hline & $(0.131)$ & $(0.16)$ & $(0.19)$ \\
\hline \multirow[t]{2}{*}{$\operatorname{lnGDP}$} & 0.151 & 0.026 & 0.033 \\
\hline & $(0.45)$ & $(0.45)$ & $(0.38)$ \\
\hline \multirow[t]{2}{*}{ Foreign Ownership } & 0.012 & $0.759 * * *$ & 0.284 \\
\hline & $(0.02)$ & $(0.18)$ & $(0.34)$ \\
\hline \multirow[t]{2}{*}{ Legal Rights } & $0.186^{*}$ & $0.195 * * *$ & $0.188 * * *$ \\
\hline & $(0.09)$ & $(0.04)$ & $(0.02)$ \\
\hline \multirow[t]{2}{*}{ Constant } & $6.457 * * *$ & $7.399 * * *$ & $5.164 * * *$ \\
\hline & $(2.13)$ & $(2.15)$ & $(1.53)$ \\
\hline
\end{tabular}




\begin{tabular}{|l|c|c|c|}
\hline Number of Banks & 168 & 168 & 168 \\
\hline First stage F-Test & 1.25 & 1.64 & 1.98 \\
\hline Prob>F & 0.000 & 0.000 & 0.000 \\
\hline Hansen's J & 0.014 & 0.87 & 1.37 \\
\hline P-value & 0.895 & 0.514 & 0.381 \\
\hline
\end{tabular}

Notes: ***,**, * stand for significance levels at the 1\%,5\% and 10\%. Models 1, 2 and 3 regress the Return on Assets (ROA) on Lerner Index, HHI Deposits and HHI Total Assets (measures of market power) respectively. Included in each model are common control variables.

Table 6 presents results when using the return on assets (ROA) as the dependent variable and the Lerner Index, HHID and HHITA as the respective market power proxies in Models 1,2 and 3. An increase in ROA implies an increase in bank profitability and possibly financial stability. In all the three models, we find a positive relationship between ROA and the different measures of market power. This implies that there is a positive relationship between financial stability and market power, again confirming the competition-fragility hypothesis. This positive outcome extends to the relationship between legal rights and ROA, implying that an improvement in legal rights enhances profitability and financial stability. Model 2 also shows a positive and statistically significant relationship between foreign bank ownership and financial stability. The positive relationship between legal rights and stability indicators was also robust, suggesting that African governments should come up with policies aimed at improving property-rights systems. This is important, especially given the current debate in a number of countries concerning the ownership of resources like mines and land. African governments need to come up with coherent and clear policies on ownership and property rights assignment. On the contrary, a negative relationship exists between the fixed assets/total assets ratio and financial stability in Model 3. This implies that more illiquid banks will not earn as highly as a liquid bank would.

\section{CONCLUSION}

Banking literature is divided into the theory that states that competition is good for financial stability and the theory that argues that bank competition is bad for financial stability. This study attempted to investigate the relationship between banking-sector competition and stability; that is, is competition in the banking sector good or bad? This is an important question in both developed and developing economies, especially given the devastating effects of the current global financial crisis. Using data from ten African countries over the period 2005-2010, this study investigated the relationship between bank competition and financial stability. It used three stability indices and three competition indices to further understand the relationship. The empirical results suggest that all the market power proxies are positively related to ROA and the Z-index, implying that an increase in market power increases financial stability. This suggests that there is a trade-off between competition and financial stability, supporting the so-called competition-fragility hypothesis. The market-power proxies are also negatively related to the NPL ratio, again confirming the competition-fragility hypothesis. Our findings corroborate those by Keeley (1990), Allen and Gale (2000; 2004), Besanko and Thakor (2004), and Edwards and Mishkin (1995).

When it comes to the relationship between market power and other variables, we find a number of interesting results. For example, improving legal rights was found to enhance financial-sector stability, suggesting that African governments should come up with policies aimed at improving property-rights systems. This is especially important given the current debate in a number of countries concerning the ownership of resources like mines and land. African governments need to come up with coherent and clear policies on ownership and propertyrights assignment. The positive relationship between GDP per capita and financial-sector stability suggests that high-income countries tend to have more stable banking sectors. The results also suggest that foreign ownership of banks tends to be stability-enhancing. If one assumes that the foreign owners of local banks are from developed economies where corporate governance systems are well developed, one can conclude that an improvement in corporate governance systems can enhance African banking-sector stability. Finally, our results suggest that the alliance between African banks through mergers and acquisitions may not necessarily destabilise the financial sectors in Africa; instead, this may actually act as a catalyst in facilitating access to finance for enterprises and households, ultimately spurring the much needed economic growth and reducing unemployment and rampant poverty. 


\section{AUTHOR INFORMATION}

Mr. Christopher Hope holds a Master's degree in Economics from Witwatersrand University, South Africa. E-mail: chris@bobhope.co.za

Dr. Tendai Gwatidzo is a senior lecturer at Witwatersrand University's School of Economics and Business Sciences, South Africa. He specialises in applied microeconomics and financial economics. E-mail: tendai.gwatidzo@wits.ac.za

Dr. Miracle Ntuli is a senior lecturer at Witwatersrand University's School of Economics and Business Sciences, South Africa. She specialises in applied microeconomics. E-mail: miraclenb@yahoo.com

\section{REFERENCES}

1. Allen, F., \& Gale, D. (2000). Comparing financial systems. Cambridge, MA and London: MIT Press Books, 1.

2. Allen, F., \& Gale, D. (2004). Competition and financial stability. Journal of Money, Credit, and Banking, 36(3), 453-480.

3. Barth, J., Caprio, G., \& Levine, R. (2001). The regulation and supervision of banks around the world: A new database. Bank Regulation and Supervision (updated dataset), WB Policy Research Working Paper No. 2588.

4. Barth, J., Caprio, G., \& Levine, R. (2004). Bank regulation and supervision: what works best? Journal of Financial Intermediation 13, 205-248.

5. Beck, T. (2008). Bank Competition and Financial Stability: Friends or Foes? Policy Research Working Paper Series 4656, The World Bank. Accessed (15 February 2013), available from: http://ideas.repec.org/p/wbk/wbrwps/4656.html\#biblio

6. Beck, T., De Jonghe, O. and Schepens, G. (2012). Bank competition and stability: cross-country heterogeneity. Journal of Financial Intermediation. Article in Press.

7. $\quad$ Berger, A. N., Klapper, L. F., \& Turk-Ariss, R. (2009). Bank Competition and Financial Stability. Journal of Financial Services Research, 35(2), 99-118.

8. Berger, A. N., Demirgüç-Kunt, A., Levine, R., \& Haubrich, J. G. (2004). Bank Concentration and Competition: An Evolution in the Making. Journal of Money, Credit and Banking, 36(3), 433-451.

9. Besanko, D., \& Thakor, A.V. (2004). Relationship Banking, Deposit Insurance and Bank Portfolio Choice. Finance 0411046. Accessed (15 February 2013, available from: http://ideas.repec.org/p/wpa/wuwpfi/0411046.html.

10. Boot, A. W. A., Greenbaum, S. I., \& Thakor, A. V. (1993). Reputation and Discretion in Financial Contracting. The American Economic Review, 83(5), 1165-1183.

11. Boyd, J. H., \& De Nicolò, G. (2005). The Theory of Bank Risk Taking and Competition Revisited. The Journal of Finance, 60(3), 1329-1343.

12. Boyd, J. H., De Nicolo, G., Jalal, A. M. (2006). Bank Risk-Taking and Competition Revisited: New Theory and New Evidence, IMF Working Paper, 06/29.

13. Boyd, J. H., De Nicolò, G., \& Jalal, A. M. (2009). Bank Competition, Risk and Asset Allocations. IMF Working Paper 09(143).

14. Boyd, J. H., \& Runkle, D. E. (1993). Size and Performance of Banking Firms: Testing the Predictions of Theory. Journal of Monetary Economics, 31(1), 47-67.

15. Caminal, R., \& Matutes, C. (2002). Market Power and Banking Failures. International Journal of Industrial Organization, 20(9), 1341-1362.

16. Carbó, S., Humphrey, D., Maudos, J., \& Molyneux, P. (2009). Cross-Country Comparisons of Competition and Pricing Power in European Banking. Journal of International Money and Finance, 28(1), 115-134.

17. Carletti, E. \& Hartmann, P. (2002). Competition and Stability: What's Special About Banking? ECB Working Paper No.146, European Central Bank. Accessed (10 February 2013), available from: http://ideas.repec.org/p/ecb/ecbwps/20020146.html.

18. Carletti, E., Vives, X. (2009). Regulation and Competition Policy in the Banking Sectorl X. Vives (ed.), Competition Policy in Europe: Fifty Years of the Treaty of Rome, Oxford University Press.

19. Claessens, S., \& Laeven, L. (2004). What Drives Bank Competition? Some International Evidence. Journal of Money, Credit and Banking, 36(3), 563-583. 
20. De Nicolò, G. (2000). Size, Charter Value and Risk in Banking: An international perspective. No 689, International Finance Discussion Papers. Board of Governors of the Federal Reserve System (US), Accessed (13 February 2013), available from: http://econpapers.repec.org/RePEc:fip:fedgif:689

21. De Nicolo, G., Bartholomew, P., Zaman, J. and Zephirin, M. (2004). Bank Consolidation, Internationalization, and Conglomeration: Trends and Implications for Financial Risk. Financial Markets, Institutions \& Instruments, 13 (4): 173-217.

22. De Nicolo, G., and Loukoianova, E., (2007). Bank Ownership, Market Structure and Risk, IMF Working Paper, 07/215.

23. Diamond, D.W., \& Dybvig, P. (1983). Bank Runs, Deposit Insurance and Liquidity. Journal of Political Economy, 91(3), 401-419.

24. Edwards, F. R., \& Mishkin, F. S. (1995). The Decline of Traditional Banking: Implications for Financial Stability and Regulatory Policy. Federal Reserve Bank of New York Economic Policy Review, 1(2), $27-45$.

25. Hall, A. R. (2005). Generalized Method of Moments. Oxford University Press, US.

26. Hansen, L. P. (1982). Large Sample Properties of Generalized Method of Moments Estimators. Econometrica: Journal of the Econometric Society, 50, 1029-1054.

27. Hellmann, T. F., Murdock, K. C., \& Stiglitz, J. E. (2000). Liberalization, Moral Hazard in Banking, and Prudential Regulation: Are Capital Requirements Enough? American Economic Review, 90(1), 147-165.

28. Hoggarth, G., \& Saporta, V. (2001). Costs of Banking System Instability: Some Empirical Evidence. Financial Stability Review, 148-165.

29. Jimenez, G., Lopez, J. A. and Saurina, J. (2010). How does competition impact bank risk taking? Banco de Espania working paper series. Accessed (12 February 2013), available from http://www.bde.es

30. Keeley, M. C. (1990). Deposit Insurance, Risk, and Market Power in Banking. The American Economic Review, 80(5), 1183-1200.

31. King, R. G., \& Levine, R. (1993). Finance, Entrepreneurship and Growth: Theory and Evidence. Journal of Monetary Economics, 32(3), 513-542.

32. Liu, H., Molyneux, P. \& Wilson, J.O.S. (2010). Measuring Competition and Stability: Recent Evidence For European Banking. Istituto Einaudi Working Paper. Accessed (12 February 2013), available from: http://istein.it/e-library/working-papers/item/2380-measuring-competition-and-stability-recent-evidence-foreuropean-banking.html.

33. Marcus, A. J. (1984). Deregulation and bank financial policy. Journal of Banking and Finance 8, 557-565.

34. Mishkin, S. (1999). Financial Consolidation: Dangers and Opportunities. Journal of Banking \& Finance, 23(4), 675-691.

35. Nkurunziza J. D., Ndikumana, L. and Nyamoya, P. (2012). The financial sector in Burundi. NBER Working paper Number 18289.

36. Panzar, J. C., \& Rosse, J. N. (1987). Testing for "Monopoly" Equilibrium. The Journal of Industrial Economics, $35(4), 443-456$.

37. Roy, A.D. (1952). Safety First and the Holding of Assets. Econometrica: Journal of the Econometric Society, 20(3), 431-449.

38. Shaffer, S. (1993). A test of competition in Canadian banking. Journal of Money, Credit and Banking, 25(1), 49-61.

39. Shaffer, S. (2003). Patterns of competition in banking. Journal of economics and business, 56(4), $287-313$.

40. Shaffer, S. (2004). Comment on "What Drives Bank Competition? Some International Evidence" by Stijn Claessens and Luc Laeven. Journal of Money, Credit and Banking, 36(3), 585-592.

41. Smith, B.D. (1984). Private Information, Deposit Interest Rates and the "Stability" of the Banking System. Journal of Monetary Economics, 14(3), 293-317.

42. Turk-Ariss, R. (2010). On the Implications of Market Power in Banking: Evidence from Developing Countries. Journal of Banking \& Finance, 34(4), 765-775.

43. Uhde, A., and Heimeshoff, U. (2009). Consolidation in banking and financial stability in Europe: empirical evidence Wirtschaftspolitik und Quantitative Wirtschaftsforschung discussion paper series, No. 02/2009

44. Vives, X. (2001). Competition in the Changing World of Banking. Oxford Review of Economic Policy, 17(4), 535 . 
NOTES 